\title{
The ministering and flying status of angel: Analysis of the image of Mrs.Klima in The Farewell Waltz
}

\author{
Liu Zhuo \\ Xi'an Fanyi University, Xi'an 710105, China \\ 20926246@qq.com
}

Key words: Male Gaze, Female Consciousness, The Farewell Waltz

\begin{abstract}
The text utilized feminism gaze theory in analysising Mrs. Klima, whose image reflected sleeping and awaking of female's self-consciousness under the oppression of patriarchy, vividly demonstrated Milan Kundera's ambivalent attitude toward women. The Farewell Waltz is one of the major works of Milan Kundera, it has won Italian Award for Best Foreign Literary. The novel took Soviet invasion of Prague as political background, through telling complicated stories of eight characters, philosophically disscussed complicated problems of life. Among these characters, Mrs.Klima is definitely an impressive one. Through the image of Kamila, Milan Kundera deeply described the sleeping and awaking process of female's self-consciousness under the oppression of patriarchy.
\end{abstract}

\section{Ministering angel—sleeping of kamila's female consciousness}

As one of heroines in “The Farewell Walts”, Mrs.Klima, Kamila was young, beautiful, graceful, but phisically weak, and has no child. However, this admired noble woman showed up with depressed appearance, because she was always suspicious and jealous of his unfaithful trumpeter husband. For her, husband was "the only man in the world". When her husband klima brought her flowers the day before her birthday and told her that he was going to the spa town for performance instead of accompanying her, Kamila was engulfed by jealousy and could not control her emotion "making the pained, violent movement of pouring an excessive amount of salt into the food." With every oversalted mouthful Klima tested Kamila's tears. He "suddenly experienced, in a single instant, her entire essence......for the woman who had loved him when he was still a nobody, who had been ready to sacrifice everything for him, who so understood his thoughts”.

The word "angel” is a religious term which refers in particular to spirits serving god, god sent them to help people who need help. "Are they not all ministering spirits, sent forth to minister for them who shall be heirs of salvation?” The word “ministering” identified angel a servent, but noble, holiness, beauty, and love are all have natural ties with angel. The English writter Virginia Woolf called women "Angel in the house”, for women's status and images agree with that of the angel. Kamila is beautiful, elegant, and delicate, her appearance and temperature reflect the pretty and delicate image of angel; her job as a seceratery obtained under the help of Klima, demonstrating Kamila economically and vocationally depends on her husband; The word "so understood", "sacrifice" show that Kamila emotionally centers on her husband. She is suspicious of her husband faithfulness, but she still tried her best to surpress inner jealous pain and served a dinner for her husband. Such inferior status down to earth is just the status of ministering angel.

In the position of ministering Kamila, the author used the word "experienced", namely Klima 
“experienced” her essence, this is a kind of power from male gaze. So, what is male gaze?

In 1970's, the English art critic John Berger made a point "gender consciousness in gaze” in his book "Ways of Seeing”, When talked about male gaze, he said: "The surveyor of woman in herself is male: the surveyed female. Thus she turns herself into an object -- and most particularly an object of vision: a sight." From this we can see that "gaze"is not common watching. Foucault remarked: "There is no need for arms, physical violence, material constraints. Just a gaze. An inspecting gaze, a gaze which each individual under its weight will end by interiorisation to the point that.....”.

The right of "viewing" was granted to viewers, and viewers confirmed their mainstay status through "viewing"; people who was viewed by others turned into the object of "viewing”, and materialized themselves in accordance with value judgement of the viewers. "Male gaze" is a kind of sexual gaze, and a way that men use power to control women. Specifically, male is the viewer and female is the object of viewing and controlling. Men's eyesight played a decesive role in casting their desires and illusions on female and they obtained pleasure in the process. In "Visual Pleasure and Narrative Cinema", Laura Mulvey quoted Budd Boetticher's view: "What counts is what the heroine provokes, or rather what she represents. She is the one, or rather the love or fear she inspires in the hero, or else the concern he feels for her, who makes him act the way he does. In herself the woman has not the slightest importance."

Male gaze can be seen in various of literature texts, on the basis of previous rules in patriarchal society: male oriented. The potential but powerful right allows writters to internalize male's value and aesthetic orientation into female's self and subject consciousness, makes women lost their own subject consciousness and became so called "object" and "vision". When read texts, just like read history and aesthetics, readers have to keep vigilant against hidden patriarchy violence that imposed on female images, because the violence is cast by men's gaze.

Return to "The Ferawall Waltz", we can find that the fact that Kamila regarded man as the first and served to man was what Klima "saw". This reflects that women were inferior to men, also shows that women were enslaved by men. As the opposite of men, women were incidential for and the object in existence level continuously denied by men. Obverously, Kamila's image at this moment textually showed and intensified the reality that men enjoy higher status than women.

\section{Flying Angle_- Awakening of Kamila's Female Consciousness}

Kamila increasingly suffering pain that came from jealousy, this jealous psychology originated from the awakening of female's self-consciousness. Previously, Kamila had lived under the control of traditional patriarchy society and her female self-consciousness was in heavy sleep. Her doubt on the faithfullness of her husband caused her jealousy, she suddenly realised that she could do nothing, and she even imagined to go to the spa town and track her husband. This illusion "tracking" is a fight against male gaze, an implicit expression of female under the patriarchy supression, the instinctive reaction of femalefacing marriage problems, and a proof of female's supressed life. Under the lead of the implicit female consciousness, Kamila untimately asked for a leave and went to the spa town. Just in here, her female consciousness completely awakened and released when she met a strang man Jakub.

Jakub is one of the heroines of "The Farewell Waltz". Because of participating in political campaign, he had been prisoned for fifteen years, he took poison along him and was ready to death. He had ever believed that what drove him toward women was a desire for revenge, or sadness and dissatisfaction, their beauty and charm were always something incidental for him. However, on the day he was going abroad and starting new life in other country, he met Kamila by chance. 
Kamila's beauty stunned and inspired him. In Jakub’s eyes, Kamila represented and integrated into beauty, she leaded him into the kingdom of beauty where he had never steped in. In this kingdom, Jakub saw " only the ecstasy of beauty mysteriously awakened by the beat of her footsteps, by the touch of her voice." He couldn’t help saying to Kamila "I'd do anything to win you. I'd abandon everything and live my whole life differently, only for you and because of you." After the meet determined by god, Jakub finally understood that he had been living like a blind man. Kamila's female beauty was the director factor that enlightened jakub to find the hidden side of his destiny, the reverse of his biography.

Jakub “contemplated” Kamila with full pleasure, "looks deeply into her eyes” definitely gazed her on male perspective. He, with masculine identity hold the initiative, pointed out the Kamila's importance for man's existance: she is a sign of destiny, "she proclaimed to him that one could live here in a different way and for something different, that beauty is more than justice, that beauty is more than truth, that it is more real, more indisputable, and also more accessible, that beauty is superior to everything else.” She represents the other hand of destiny covered by man.

But to Kamila, Jakub's gaze as a man in return became an opportunity and tool that facilate pomplete awakening of Kamila's female consciousness. When man, on the station of emperor, confirmed the value of female, Kamila re-understand herself. She watched the strenger go with gentle eyes. It is her gaze rather than watching marked her full liberation from the status depressed and strained by male's patriarchy. Kamila became independent and confident, no more a wife extremely worrying about her husband.

"She was unable to forget them......The man had told her that he had lived all his life like a blind man, that he had not even suspected that beauty exists. She understood him. Because it was the same with her. She, too, lived in blindness. She had been seeing only a single being lit up by the floodlight of her jealousy. And what would happen if that floodlight abruptly went out? In the unfocused light of day other beings would suddenly appear by the thousands, and the man she had up until now believed was the only one in the world would become one among many."

This part of internal monologue reflects that Kamila deeply realized her existence. For Kamila, Jakub was a tool, a symble and a indication of destiny, she also found another possibility of life. Jakub's words broadened her horizon and made her not just put eyes on her husband. However, she had"a yearning for all the opportunities she had let pass, escape, evaded, even for those she had never had." "She reflected that somewhere ahead on the road of her life a line indicating the breakup with the trumpeter had already been traced. For the first time, this idea inspired neither anxiety nor fear in her.” Obviously, the woman who had regarded husband as her prime want began to attach importance to individual values and feelings rather than primarily focus on her husband.The awakening of self-consciousness means the angel had leaped over ministering status.

\section{Conclusion}

In “The Farewall Waltz”, Milan Kundera, through depicting Mrs.Klima, successfully portrayed the process from sleep to awakening of female's self-consciousness, this has universal significance. One interesting point is that although male gaze is an expression of patriarchy, but it does help to the awakening of female's self-consciousness. The ironic effect is just what Milan Kundera contributed to feminism gaze theory in practice, and also reflects the author's contradictory views on female. 


\section{Acknowledgements}

Funded Item: 2014 Special Fund for the Planning of Xi'an Social Sciences (Item Number: 14XF20)

\section{References}

[1] [Czech] ,Milan Kundera.The Farewell Waltz [M].Translated by Yu Zhongxian.Shanghai: Shanghai Translation Publishing House,2004,21

[2] [Czech] ,Milan Kundera.The Farewell Waltz [M].Translated by Yu Zhongxian.Shanghai: Shanghai Translation Publishing House,2004,24

[3] [Czech],Milan Kundera.The Farewell Waltz [M].Translated by Yu Zhongxian.Shanghai: Shanghai Translation Publishing House,2004,24-25

[4] National Committee of Three-Self Patriotic Movement of the Protestant Churches in China (National TSPM）.China Christian Council（CCC）,The Teachings and Works of Jesus [Z] .2003,244

[5][British]John Berger.Ways of Seeing[M].Translated by Dai Xingyue.Shanghai,The Commercial Press,1994,44

[6] Quoted from Li Yinhe.Feminism [M] .Jinan,Shandong People’s Publishing House,2005,68 